\title{
THE EFFECT OF SOCIAL CAPITAL ON CUSTOMER'S REPAYMENT RATE AT ISLAMIC MICROFINANCE INSTITUTION
}

\author{
Jaenal Effendi, Annisa Rindra Utami
}

\begin{abstract}
The Effect of Social Capital on Customer's Repayment Rate at Islamic Microfinance Institution. The potency of Micro and Small Enterprises (MSEs) in Indonesia which is great, is not directly proportional to the ease of getting capital from formal financial institutions such as banks because it is not bankable. Meanwhile, microfinance institutions (MFIs) that provide financing to the MSEs are currently thriving. This condition exposes the existence of factors that cause the MFIs continuesly providing financing to MSEs which are not bankable. This research aims to analyze the effect of social capital toward the repayment rate of Islamic MFIs' customers. The methods used in this research was the logistic regression. The results showed variable relationship with BMT employees, relations with other customers, and Islamic recitation had positive and significant effect toward the repayment rate of the customer. While recommendations, membership status, and travel time from home to the BMT had negative and significant effect. Variable outside the social capital indicator which is income rate had no significant effect.
\end{abstract}

Keywords: logistic regression; microfinance institution; repayment rate; social capital

\begin{abstract}
Abstrak. Pengarub Modal Sosial Terhadap Tingkat Pengembalian dari Nasabab Pada Lembaga Keuangan Syariah. Potensi Usaha Mikro dan Kecil (UMK) di Indonesia yang besar, tidak berbanding lurus dengan kemudahan mendapatkan modal dari lembaga keungan formal seperti bank karena dianggap tidak bankable. Padahal saat ini berkembang pesat lembaga keuangan mikro (LKM) yang memberikan pembiayaan kepada UMK. Kondisi ini memperlihatkan adanya faktor-faktor yang menyebabkan LKM terus memberikan pembiayaan kepada UMKyang dianggap tidak bankable. Penelitian ini bertujuan untuk menganalisis pengaruh modal sosial terhadap repayment rate LKM Syariah. Metode yang digunakan dalam penelitian ini adalah regresi logistik. Hasil penelitian menunjukkan variabel hubungan dengan karyawan BMT, hubungan dengan nasabah lain, dan pengajian berpengaruh positif dan signifikan terhadap repayment rate nasabah. Sementara variabel rekomendasi orang, status keanggotaan, dan waktu tempuh dari rumah ke BMT berpengaruh negatif dan signifikan. Variabel di luar indikator modal sosial, yaitu tingkat pendapatan tidak berpengaruh signifikan.
\end{abstract}

Kata kunci: regresi logistik; lembaga keuangan mikro; tingkat pengembaian; modal sosial 


\section{Introduction}

Access to microfinance institutions economically helps not only poor borrowers, but their community, as well (Khandker 2005). Poor people usually lack access to banks' financial services, because of their stringent application requirements. Therefore, establishing microfinance institutions (MFIs) in developing communities may help poor entrepreneurs start new businesses, reduce people's vulnerability to external factors, and enable them to earn enough income to cover their expenditures. MFIs provide financial services using simple administrative procedures and generally without requiring collateral, avoiding the pitfalls of conventional banking whilst having an opportunity to improve the welfare of their clients. Furthermore, the reach of microfinance extends beyond urban areas, with MFIs commonly being found in remote areas and regularly maintaining relationships with their clients in these areas. Through these relationships, MFIs create a connection between themselves and clients, enabling them to assist with clients' financial problems, educate them on environmental matters, and join in providing aid to communities following natural disasters. Some of these disasters—or their consequences_are avoidable through proper environmental maintenance; however, without access to financial institutions and thus greater financial opportunity, compounded by limited skills, knowledge, and competitiveness, the poor are prevented from seeking occupations that are not dependent on the exploitation of the environment. Overexploitation of natural resources usually occurs as a result of low environmental awareness, creating ecosystem and environmental degradation. Hence, microfinance, with its ability to connect with clients and more effectively run social programs dedicated to education and environmental training, is considered to have an important role in alleviating poverty and reducing environmental degradation.

Donors, governments, and NGOs worldwide have become aware of microfinance's important potential roles and prospects (Hermes and Lensink 2011). The United Nations (UN) declared 2005 as the International Year of Microcredit, which is essential to reaching their millennium development goals, one of which is halving the world's poverty rate by 2015. Furthermore, MFIs also have the opportunity to positively contribute to ensuring environmental sustainability, one of the UN's other millennium development goals. Microfinance, according to Lashley (2004), is a concept that has been growing in popularity ever since the establishment of Grameen Bank in Bangladesh in the early-1970s. Since then, MFIs have spread all over the world as a means of both poverty alleviation and microenterprise development.

In Indonesia, microfinance is an essential component of enabling the poor 
to take part in economic activities, since they are excluded from formal banking. According to Ledgerwood (1999), microfinance clients consist of self-employed farmers, non-agricultural workers, as well as low-income entrepreneurs. They generally generated income as traders, street vendors, small farmers, service providers, craftsmen, or small producers. Microfinance programs help clients generate income through the creation of new jobs, whether in micro, small, or medium enterprises (MSMEs), consequently reducing unemployment rates.

A significant majority of Indonesians derived their incomes from a micro enterprise; 54,559,969 in 2011, 56,534,592 in 2012, and 57,189,393 in 2013 which is around $99 \%$ every year (Table 1). Conversely, just 4,952 in 2011, 4,968 in 2012, and 5,066 in 2013 which, around $0.01 \%$ in every year were large enterprises. Prevalence of enterprises decreased with the increase in their scale; thus, small enterprises accounted for 602,195 in 2011, 629,418 in 2012, and 654,222 in 2013, while medium enterprises accounted for 44,280 in 2011, 48,997 in 2012, and 52,106 in 2013 . On the micro scale, these percentages had a significant effect on job opportunities, with $94,957,797$ (2011), 99,859,517 in (2012), and 104,624,466 (2013) of people being employed in micro enterprises. On the other hand, just 2,891,224 in 2011, 3,150,645 in 2012, and 3,537,162 in 2013 were employed in large enterprises. Therefore, micro, small, and medium enterprises made significant contributions to the labor market.

Table 1. MSMEs in Indonesia, 2011-2013.

\begin{tabular}{lrrr}
\hline \multicolumn{1}{c}{ Indicators } & \multicolumn{1}{c}{$\begin{array}{c}\mathbf{2 0 1 1} \\
\text { Total }\end{array}$} & \multicolumn{1}{c}{$\begin{array}{c}\mathbf{2 0 1 2} \\
\text { Total }\end{array}$} & \multicolumn{1}{c}{\begin{tabular}{r}
\multicolumn{1}{c}{ To13 } \\
Total
\end{tabular}} \\
\hline Enterprise Scale (unit) & & & \\
Micro & 54.559 .969 & 56.534 .592 & 57.189 .393 \\
Small & 602.195 & 629.418 & 654.222 \\
Medium & 44.280 & 48.997 & 52.106 \\
Large & 4.952 & 4.968 & 5.066 \\
Employees (people) & & & 104.624 .466 \\
Micro & 94.957 .797 & 99.859 .517 & 5.570 .231 \\
Small & 3.919 .992 & 4.535 .970 & 3.949 .385 \\
Medium & $2.844,669$ & 3.262 .023 & \\
Large & 2.891 .224 & 3.150 .645 & \\
\hline
\end{tabular}

Source: Ministry of Cooperative and Small and Medium Enterprises (2015). 
The amount of MSMEs, that contributed to reduce unemployment in Indonesia and GDP shows the potential of MSEs if it can be developed better. One way to develop MSEs is improving access to sufficient capital. One of the microfinance institutions that provide access to capital for MSEs is Baitul Maal wat Tamwil (BMT). BMT is an alternative source of capital of MSEs that considered unbankable by the formal financial institutions. BMT is one of the microfinance institutions that provide solutions for MSEs to obtain capital. BMT can be an alternative for MSEs because of the requirements given to apply for financing more easily than formal financial institutions. Location of BMT is also usually more accessible to MSEs that are not located in the city center.

BMT financing provided to customers should be returned in the period that has been agreed by the BMT and the customer in the beginning of the contract. Customers do not always give the return well, which in turn affects the level of fluency rate of return or repayment rate. Many factors cause the customer is not able to carry out the financing with better returns. One of external factors that cause customer pay the returns unwell is a bad condition of their business. One of internal factors that cause customer pay the returns unwell is moral hazard.

BMT, in providing financing to MSEs applying Islamic principles. That means, BMT uses the applicable contract and provisions accordance with Islamic law. BMT also integrate spiritual values, ethics, and morals, uphold kinship and togetherness (Soemitra 2009). This indicates the existence of indicators of social capital applied BMT in carrying out its functions. This research used logistic regression to examine the impact between the variables studied both indicator of social capital and are not indicator of social capital. The aim of this study was to analyze the influence of social capital factors toward the customer's repayment rate of Islamic microfinance institutions.

\section{Literature Review}

Microfinance institutions (MFIs) often start as non-profit enterprises with the social goal of helping the poorest to access financial services (Maier and Pischke, 2006). Their establishment is made possible by grants and donations from private donors and development agencies, and as they develop, maintaining their provision of services to poor clients becomes a main imperative. Independence from initial subsidies, through the ability to generate their own profits, becomes essential to sustainability. Amongst conventional MFIs, this is achieved through the use of interest, while Islamic MFIs, prevented by Islamic law from using interest, implement profit-sharing schemes and accept public donations.

Grameen Bank, considered a pioneer amongst microfinance institutions, has 
successfully provided financial services to the peoples of Bangladesh for nearly forty years, much of them credit schemes through group lending. It also partakes in a number of social programs, such as capacity building and programs empowering women and beggars. However, this institution is known to use interest-based schemes (Meisami. et.al, 2011). Islamic MFIs have their own inherent characteristics that help mitigate the financial risks faced by conventional MFIs (Ahmed, 2002). Some principle differences between conventional and Islamic microfinance is presented in Table 2.

Additionally, Islamic microfinance is able to exploit charity funds, such as zakat, infaq, and shadaqah, as their fund sources for delivering financing, whereas conventional microfinance does not have access to these capital sources. However, conventional microfinance can use interest as a method of increasing income, while Islamic microfinance is instead required to provide other schemes that still remain compliant with Islamic laws (Rahman, 2007). The need to employ Islamic principles in Islamic finance, such as avoiding riba, gharar, jahl, darar, and other unfair business practices, does not mean Islamic MFIs have limited financial products. Islamic microfinance employs several methods of fund mobilization and financing, and uses a monitoring system for managing risk (Obaidullah and Khan, 2008).

Table 2. Differences between conventional and Islamic MFIs.

\begin{tabular}{|c|c|c|}
\hline Item & Conventional MFI & Islamic MFI \\
\hline Liabilities (sources of funds) & $\begin{array}{l}\text { External funds, clients' } \\
\text { savings }\end{array}$ & $\begin{array}{l}\text { External funds, clients' savings, } \\
\text { charity-based sources }\end{array}$ \\
\hline Assets (mode of financing) & Interest-based & Islamic law-based \\
\hline Financing the poorest & Poorest are left out & $\begin{array}{l}\text { Poorest can be reached through } \\
\text { integrating charity-based funds } \\
\text { with microfinance }\end{array}$ \\
\hline Funds transfer & Cash transferred & Goods transferred \\
\hline $\begin{array}{l}\text { Deduction at inception of } \\
\text { contract }\end{array}$ & $\begin{array}{l}\text { Part of the funds deducted } \\
\text { at inception }\end{array}$ & No deduction at inception \\
\hline Target group & Women & Family \\
\hline $\begin{array}{l}\text { Liability of the loan (when } \\
\text { given to women) }\end{array}$ & Recipient & Recipient and spouse \\
\hline Employee motivations & Monetary & Monetary and religious \\
\hline Dealing with default & $\begin{array}{l}\text { Group/center pressure and } \\
\text { threats }\end{array}$ & $\begin{array}{l}\text { Group/center/spouse/guarantee } \\
\text { and Islamic ethics }\end{array}$ \\
\hline Social development program & $\begin{array}{l}\text { Secular (or non-Islamic) } \\
\text { bahavior, ethical, and social } \\
\text { development }\end{array}$ & $\begin{array}{l}\text { Religious (includes behavior, } \\
\text { ethics, and social) }\end{array}$ \\
\hline
\end{tabular}

Source: Ahmed (2002) 
Some studies reveal the positive roles of religious beliefs and spirituality on the development process (De Kadt, 2009; Lunn, 2009; Ter Haar and Ellis, 2006). Religion can support the economic welfare of the societies in which it is found, particularly when it is involved in providing financial services. Fernando (2007) points out that access to finance is a central issue in development, in terms of growth, poverty, social development, and equity. Thus, bridging religious institutions and the financial sector is important to support human development (Mirghani. et.al, 2011). Mersland, D'espallier, and Supphellen (2013) measured the performance differences between Christian and secular microfinance institutions, specifically in their economic development contributions to society. Their findings revealed that Christian MFIs' performance indicators were based on social, rather an economic, factors.

Conventional MFIs have low penetration in low-income Muslim communities because these communities would prefer to adopt Islamic law-compliant finance (Wilson, 2007). As a result, in recent decades, Islamic microfinance has shown promise as institutions see an increase in market demand and greater participation in international finance. These institutions are based on Islamic principles, such as the prohibition of interest-based lending, conducting unfair or exploitative economic activities, giving or receiving bribes, or determining return percentages on financial transactions (Karim et.al, 2008; Seibel, 2008). Promoting Islamic microfinance according to Seibel (2008) can be done through encouraging Islamic commercial banks to create units for Islamic microfinance, and reappraising Islamic rural banks and cooperatives on their challenges and opportunities.

Islamic finance involves providing financial services to clients using Islamic principles, such as brotherhood, solidarity, and partnership. Furthermore, institutions and clients usually share the benefits and risks of their transactions in accordance with the contributions they support (Seibel and Wahyu, 2006). According to Gait and Andrew (2009), the main products of the Islamic financial system are mudarabah (partial equity partnership), musharakah (full equity partnership), murabaha (financing for purchasing goods), bai bi tsaman 'ajil (deferred payments on products), bai salam (advance sale contracts), istisna (manufacturing contract system), ijarah (lease financing), and qard al hasan (credit without interest). While targeting the poor is the main objective of microfinance, reaching the poorest of the poor is associated with higher risks, and therefore presents a problem for some institutions. Islamic microfinance, with its access to social funds such as zakat, infaq, and shadaqah helps it reach the poorest (Mirgani et al. 2011; Kaleem and Saima, 2010). These charity funds are generally distributed by Islamic MFIs in the form of qard al hasan schemes. Through this 
social scheme, Islamic MFIs increase the potential of not just reaching the poorest, but helping them become credit-worthy and minimizing the unequal distribution of wealth within society (Smolo and Ghafar 2011; Widiyanto, Mutamimah, and Hendar, 2011).

In Indonesia, Islamic MFIs are categorized into three types: Islamic microfinance divisions of Islamic banks, Islamic rural banks (BPRS), and Islamic financial cooperatives called baitul maal wat tamwil (BMT). As BMTs' operations are supported by Islamic banks, BPRS, and big Islamic organizations such as Nahdlatul Ulama (NU) and Muhammadiyah, they have a network of more than two thousand institutions. Millions of the poor and poorest are able to access the financial services of these microfinancial institutions (Obaidullah, 2008). According to the Constitution No. 1 year of 2013 about Micro Finance Institutions (MFIs), the definition of MFI is a financial institution that is specifically established to provide business development services and community empowerment, either through a loan or financing for micro enterprises to members and public, savings management, as well as the provision of business development consulting services that is not solely for profit. One of the financial institutions that include in MFIs is Baitul Maal wat Tamwil or BMT. Based on linguistic, BMT is divided into two terms, those are baitul maal and baitul tamwil. Baitul maal serves to collect and distribute assets that are non-profit such as zakah, infaq, and shodaqoh. Baitul tamwil is a business or commercial unit of BMT. This unit is not separate from the BMT and serves as a support for middle and lower community economic activities based on Islamic principles (Karim, 2012).

BMT distributes funds to the lower middle income people in the form of financing. This study took place in BMT Khairu Ummah, Leuwiliang, Kabupaten Bogor. This BMT uses a survey system to potential funding recipients. This step is done to familiarize the prospective recipient of financing in order to reduce asimetric information between BMT and the client. In addition, BMT Khairu Ummah also introduced a system of 'jemput bola'. Customers who want to save money or pay the return do not need to come to the office due to the collector of the BMT will visit customers' homes one by one every day. That kind of Silaturrahmi is the hallmark and the way BMT builds personal closeness to customers. The closeness that has been built, form social capital between customers and BMT employee. Social capital is a characteristics of social organization such as networks, norms, and social trust that help coordination and cooperation for mutual benefit (Putnam, 1993). While, Fukuyama (1995) states that social capital is the ability of individuals to work together with others for a common purpose in groups and organizations. 
Bastelaer (2000) examined the relationship between social capital with the performance of lending program in developing countries. The results of the study that concluded by Van Basteleer is that the success of the lending program in many developing countries is largely determined by the close relationship between the borrower with funds (staff) of microfinance institutions. When the staff of financial institutions as credit provider has a close relationship with the borrower, the role of interpersonal ties is one important element that ensures the good repayment rate.

Nugroho (2008) in his study concluded that microcredit extended by strengthening mutual trust, the kinship between the borrower and the bank officers, as well as the involvement of community leaders can generate good returns. This is possible because the social capital can strengthen loyalty and provide an incentive to the borrower to be honest and return the credit extended.

Kurnia (2007) in his study showed that the indicators of capital that significantly influence the repayment rate are the relationship between members, the distance between the house members, beliefs, membership status, number of meetings, and the distance between the homes of customers with KBMT Wihdatul Ummah. While variables which not social capital indicator that have significant effect on repayment rate are capital and character. Hauberer (2011) has summarized some of the indicators of social capital that has been used by previous researchers. The social capital indicators are 1) the lives of organizations / members of the organization or association; 2) family ties; 3) social trust; 4) trust in institutions; 5) presence in the church. The indicators in this study are the adaptation of the indicators above.

\section{Methods}

The data used in this study are primary and secondary data in the form of qualitative and quantitative data. Quantitative interviews involved standardized questionnaires and semi-structured interviews. Respondents for these quantitative interviews were selected through a randomized sampling procedure, based on information provided by the directors of Islamic MFIs and village leaders, and criteria that clients had received at least one period of financing or credit and ran their own business. The primary data obtained through interviews to respondents who are micro and small enterprise that get financing from BMT and employee of BMT Khairu Ummah. Secondary data is the supporting data for this study were obtained through documents and annual reports of BMT Khairu Ummah. In addition, Secondary data were collected in print-books, journals, magazines, 
and bulletins - and electronic - statistics only found online and maps-media, the Ministry of Cooperatives and Small and Medium Enterprises, the Central Statistics Agency (BPS), Bank Indonesia, books, theses, journals and other required literature.

This research was conducted in Baitul Maal wat Tamwil Khairu Ummah located on Jalan Raya Leuwiliang, Leuwiliang, Kabupaten Bogor, as well as two branches of BMT Khairu Ummah located in the Cigudeg and Puraseda Village, Leuwiliang. BMT election is done purposively (intentionally) with consideration BMT Khairu Ummah provides financing facilities for MSEs which is in accordance with the purpose of this study. Besides that, the development of BMT Khairu Ummah is also good. This study was conducted from the second to fourth week of February 2015.

The data collected in this study using a case study of one of Islamic microfinance institutions, BMT Khairu Ummah, through questionnaires and interviews to respondents. Respondents of survey elected by using non-probability selection method (non-random), so that, not all members of the population have the same opportunity to be selected as a sample. The total number of financing partners of BMT Khairu Ummah in 2014 was 1332 individuals. The study population was all the groceries MSEs that have been given the Murabaha financing from BMT in 2014 and the running time period. Total population was 180 customers and 40 customers selected to be interviewed with the details of 37 respondents with a good repayment rate of 3 respondents with a bad repayment rate. The repayment rate data were obtained from BMT Khairu Ummah.

Data analysis method used in this research is descriptive analysis method and quantitative analysis. Descriptive analysis is used to explain the findings during the study. Quantitative data is processed using logistic regression or logit models with software EViews 7. Using logit model is to explain the behavior of a dependent variable which dummy or dichotomous. The dependent variable is 0 or 1 (Gujarati 1997).

The dependent variable used for logit models in this study is the repayment rate to code

$$
\mathrm{Y}=1 \text { (good repayment rate) and } \mathrm{Y}=0 \text { (bad repayment rate). }
$$

The independent variable of this study are the factors of social capital and supported factors associated with financing in BMT Khairu Ummah. Regression equation model can be written as follows:

$$
\mathrm{Y}=\operatorname{Ln}\left[\frac{P_{1}}{1-P_{1}}\right]=\beta_{0}+\beta X_{1}+\beta X_{2}+\beta X_{3}+\beta X_{4}+\beta X_{5}+\beta X_{6}+\beta X_{7}+\mu
$$


Where:

$$
\begin{array}{ll}
\mathrm{Y}_{1} & =\text { Repayment rate dummy } \\
\mathrm{X}_{1} & =\text { Relationships with BMT employees } \\
\mathrm{X}_{2} & =\text { Relationships with other customers } \\
\mathrm{X}_{3} & =\text { Income respondents per month } \\
\mathrm{X}_{4} & =\text { Frequency of attendance at Islamic recitation } \\
\mathrm{X}_{5} & =\text { Recommendations dummy } \\
\mathrm{X}_{6} & =\text { Members Dummy } \\
\mathrm{X}_{7} & =\text { Travel time from home to BMT (min) }
\end{array}
$$

\section{Results and Discussion}

Based on the results of data processing using Binary Logistic (logit), the results obtained in the table below. McFadden R-squared value in the equation is 0.5915 , so it can be interpreted that the independent variable in the equation can explain factors that influence customers' repayment rate BMT Khairu Ummah by 59.15 percent, the rest is explained by other variables outside the model.

Table 3. Factors of Social Capital affecting Repayment Rate

\begin{tabular}{lccc}
\hline Variable & Coefficient & Prob. & Odds Ratio \\
\hline Constant & -23.13986 & 0.1054 & $8.9225 \mathrm{E}-11$ \\
Relationship with BMT employee & 8.861243 & $0.0536^{*}$ & 7053.244481 \\
Relationship with other customer & 8.482418 & $0.0192^{* *}$ & 4829.112585 \\
Income level & 3.349163 & 0.1097 & 28.47888684 \\
Islamic recitation & 8.414511 & $0.0497^{* *}$ & 4512.068614 \\
Recommendation dummy & -9.810860 & $0.0080^{* * *}$ & $5.48527 \mathrm{E}-05$ \\
Membership status dummy & -20.34178 & $0.0522^{*}$ & $1.46446 \mathrm{E}-09$ \\
Travel time from home to BMT (min) & -0.698461 & $0.0495^{* *}$ & 0.497350137 \\
Total respondents & 40 peoples & & \\
McFadden R-squared & 0.5915 & & \\
\hline
\end{tabular}

*Significant in alpha level 10\%

** Significant in alpha level 5\%

*** Significant in alpha level 1\% 
Relationship with BMT showed close relationship and social network of customers and employees of BMT. Relationship with BMT variable showed a probability of 0.0536 thus having an effect significantly to the repayment rate on the alpha level of 10 percent. Relationship with BMT variable has positive coefficient with an odds ratio of 7053.244481 which showed a positive effect. Relationships with BMT in this study aimed to see how close is customer relationships with employees BMT. There are five categories of relationship, there are no relationship, neighbors, friends, partially family, and the wholly family. Based on these results, it means the closer customer relationships with BMT employees the chances of good repayment rate 7053.244481 times greater. Nugroho (2008) states that micro credit which is given by improving the kinship between the customer and bank officer or agency will generate better returns.

Relationships with other customers showed close relationship and social network of customers with fellow customers BMT. Variable relationships with other customers showed a probability of 0.0192 , which means a significant effect on the repayment rate at 5 percent alpha level with positive coefficient, which means relationships with other customers had positive effect. Relationships with other customers in this study aimed to see how close relationship of customer with other customers. There are five categories of relationship, there are no relationship, close neighbors, far neighbors, partially families, and wholly family. Oods ratio of the variable is 4829.112585 . Based on the results obtained, it can be interpreted that the closer the relationship between the customer with one another, chances of good repayment rate will be 4829.112585 times greater. This is consistent with research Kurnia (2007) that the customer relationship with other customers had positive effect on customer's repayment rate.

The level of income is not an indicator of social capital, but this variable needs to be researched for the study because income directly related to the repayment rate. The level of income shows the money earned by respondents every month There are six categories of income, no income, one to five million rupiahs, more than five million to ten million rupiahs, more than ten million to fifteen million rupiahs, more than fifteen million up to twenty million rupiahs, and more than twenty million. Variable income level indicates the probability of 0.1097 with a positive coefficient, which means no significant impact on customers' repayment rate. These results indicate that a large or small income does not affect customer's repayment rate. This can happen because respondent's expenditure per month is different as well. Respondents with large revenues do not necessarily have more left over money after deducted by regular expenses per month compared to respondents with lower incomes. That was the reason that led to the variable level of income is not significant in this study. 
The presence in Islamic recitation in the study indicate the transfer of social norms to customers. The more often the respondents attend to the recitation, the more values, social norms, and religion knowledge are delivered to the respondents. This variable in the study also showed social network of customers. There are five categories of this variable, never, occasionally, rarely, frequently, and always presence in Islamic recitation variable showed a probability of 0.0497 , which means had significant effect on the repayment rate on the alpha level of 5 percent. Presence in Islamic recitation variable coefficient is positive, which means recitation had positive effect on the repayment rate with an odds ratio of 4512.068614 . This variable aimed to see how often the respondents involved in activities held in their environment. The results obtained showed that the more often customers following the Islamic recitation, the chances of good repayment rate 4512.068614 times greater.

Recommended customer deemed to have been trusted by people around or society. The probability of this variable is 0.0080 , thus, it has a significant effect on the alpha level of 1 percent. The coefficient variable is negative, which means this variables has negative influence toward repayment rate. That means the chances of recommended customers' repayment rate have good repayment rate are smaller than customers who are not recommended. Recommendation from someone to BMT to recipients of financing showed the social trust of the customer, but in this case, the recommendation could be given with no depth observation to the customer so that what is used as the basis to provide recommendations do not correspond to reality. Excerpted from the statement of Mrs. Risma (Operations Division of BMT Khairu Ummah), the financing provided by recommendations, often problematic. This is because there is no direct survey from BMT Khairu Ummah to potential recipients of financing, so that the BMT less personal exposure to potential recipients of the financing. For this type of financing, apalis (the person who give recommendation) is also a guarantor although there has been collateral pledged. Because too many problems arise with this system, financing with recommendation is not allowed anymore at the moment.

Membership status showed customer participation within organizations and social networks. The probability of this variable is 0.0522 so it has significant effect on the alpha level of 10 percent, while coefficient of variable is negative, which means that this variables negatively affect the repayment rate. This means the chances of members have good repayment rate is smaller than non- members. Customers who have become members of BMT should have more closeness than customers who are not members of BMT. This is because if the customers become a member of BMT, customers involved more actively in organizing BMT. The 
intensity to meet BMT employees should also be higher because BMT members are always invited to both the regular meeting of the BMT and other events. But in this study this variable obtained negative results. From the results of interviews, Mrs. Risma (Operations Division of BMT Khairu Ummah) stated that the percentage of members that also borrowers is less than the non-member borrowers. One of the cases occurring in the field is members of BMT become apalis and borrowers are not good at returning financing. Being apalis means being guarantor as well, so that the financing given on behalf of the members. That's why the members in the category of bad repayment rate. Kurnia (2007) also stated that the membership status had significant negative impact on the repayment rate of the customer.

Variable travel time from home to BMT has probability of 0.0495 , which means significant at the alpha level of 5 percent, while the variable coefficient is negative, which indicates travel time from home to BMT has a negative relationship with the repayment rate with an odds ratio of 0.497350137 . These results can be interpreted that the longer the travel time from customers' home to BMT then the chances of good repayment rate is 0.497350137 times smaller. The travel time from home to BMT longer allow customers to get less access to information and supervision. It also makes the intensity of customers' meetings with BMT employees except collectors and customers' participation to BMT is getting smaller so the chances of bad repayment rate increases.

\section{Conclusion}

While empirical studies on whether social capital of Islamic microfinance of BMT Khairu Ummah have affected thecustomer's repayment rate are meaningful to the scientific community, they are challenging because so few have been conducted. Studies on social capital of Islamic microfinance's (BMT) effects on repayment rate, for example, are still limited. The present study was designed to examine the impacts of social capital of Islamic microfinance (BMT Khairu Ummah) on customer's repayment rate. In general, we found social capital of Islamic microfinance institutions (MFIs) of BMT Khairu Ummah to have had a more significant impact on costumer's repayment rate. In detail, social capital variables affect customers 'repayment rate of BMT Khairu Ummah. Variable of relationship with BMT, relationships with other customers, and presence in Islamic recitation have significant positive impact on customers' repayment rate. While the variable of recommendation, membership status, and the travel time from home to BMT have significant negative impact customers' repayment rate. Variable of income level is not an indicator of social capital and has no significant 
impact on customers' repayment rate. BMT Khairu Ummah should first consider the customers who have relation with BMT employees and other customers to get financing, because in this study, it is significantly proven that the customers that have a good relation with BMT employees and other customers have a good repayment rate. BMT Khairu Ummah should also conduct more frequent meetings with the customer so that the intensity of the encounter between the customer and BMT will be higher and customers not only get benefit in terms of financing, but also in other fields such as new knowledge. The further researcher is advisable to add some indicators of social capital that has not been examined in this study, such as participation in the organization, the character, and the norms of reciprocity as there are many variables social capital that has not been described in this study.

\section{References}

Ahmed, H. (2002). Financing Microenterprises: "An Analytical Study of Islamic Microfinance Instritutions. Islamic Economic Studies. Vol. 9 (2): 27-64.

Akerlof, G.A.. (1970). The Market for Lemons: Qualitative Uncertainty and the Market Mechanism. Quarterly Journal of Economics. Vol. 84:. 488-500.

Al Arif, M.N.R. (2012). Lembaga Keuangan Syariah: Kajian Teoritis Praktis. Bandung: Pustaka Setia.

Bastelaer T.V. \& H. Leathers. (2006). Trust in Lending: Social Capital and Joint Liability Seed Loans in Southern Zambia. World Development. Vol. 34 (10): $1788-1807$.

De Kadt, E. (2009). Should God Play a Role in Development? Journal of International Development. Vol. 21: 781-786.

Fukuyama, F. (1995). Trust: The Social Virtues and the Creation of Prosperity. New York: The Free Press.

Gait, A.H. \& A.C. Worthington. (2009). A Primer on Islamic Finance: Definitions, Sources, Principles, and Methods. Discussion Paper Finance 2009 (09). Griffith Business School.

Hauberer, J. (2011). Social Capital Theory: Toward a Methodological Foundation. Prague: VS Research.

Hermes, N. \& R. Lensink. (2011). Microfinance, Outreach, and Sustainability. World Development. Vol. 39 (6): 875-881.

Khandker, S.R. (2005). Microfinance and poverty: Evidence using panel data from Bangladesh. The World Bank Economic Review. Vol. 19 (2): 263-286 
Kurnia, W. (2007). Analisis Pengaruh Sosial Capital terhadap Repayment Rate pada Lembaga Keuangan Mikro Syariah (Studi Kasus KBMT Wihdatul Ummah). [Unpublished Thesis]. Bogor: Institut Pertanian Bogor.

Lashley, J.G. (2004). Microfinance and Poverty Alleviation in the Caribbean: A Strategy Overview. Journal of Microfinance. Vol. 6 (1): 83-94.

Ledgerwood, J. (1999). Microfinance Handbook: an Institutional and Financial Perspective. Washington, D.C.: The Word Bank.

Maier, I.M. et.al (ed). (2006.) Microfinance Investment Funds: Leveraging Private Capital for Economic Growth and Poverty Reduction. Berlin: Springer.

Meisami, H. et.al. (2011). Islamic vs. Conventional Microfinance: A Comparative Theoretical Analysis. International Journal of Business and Management Tomorrow. Vol.1 (1): 99-105.

Mersland, Roy. et.al. (2013). The Effect of Religion on Development Effort: Evidence from the Microfinance Industry and a Research Agenda. World Development. Vol. 41: 145-156.

Mirghani, M. et.al. (2011). Islamic Microcredit and Poverty Alleviation in the Muslim World: Prospects and Challenges. Australian Journal of Basis and Applied Sciences. Vol. 5 (9): 620-626.

Nugroho, A.E. (2008). A Critical Review of the Link between Social Capital and Microfinance in Indonesia. Jurnal Ekonomi dan Bisnis Indonesia. Vol. 23(2): 124-142..

Obaidullah, M. (2008). Introduction to Islamic Microfinance. New Delhi: IBF Net.

Putnam, R.D. (1993). Making Democracy Work: Civic Traditions in Modern Italy. United Kingdom: Princeton University Press.

Seibel, H.D. (2008). Islamic Microfinance in Indonesia: The Challenge of Institutional Diversity, Regulation, and Supervision. Journal of Social Issues in Southeast Asia. Vol. 23 (1): 86-103.

Seibel, H.D. \& W.D. Agung. (2006). Islamic Microfinance in Indonesia. Working Paper 2006 (2). Development Research Center, University of Cologne.

Smolo, E. \& A.G. Ismail. (2011). A Theory and Contractual Framework of Islamic Micro-financial Institutions' Operations. Journal of Financial Services Marketing. Vol. 15 (4): 287-295.

Soemitra, A. (2009). Bank dan Lembaga Keuangan Syariah. Jakarta): Kencana.

Ter Haar, G. \& S. Ellis. (2006). The Role of Religion in Development: Towards a New Relationship between the European Union and Africa. The European Journal of Development Research. Vol. 18 (3): 351-367. 
Widiyanto, S.M. \& Hendar. (2011). Effectiveness of Qard al Hasan Financing as a Poverty Alleviation Model. Economic Journal of Emerging Markets. Vol. 3 (1): 27-42.

Wilson, R. (2007). Making Development Assistance Sustainable through Islamic Microfinance. IIUM Journal of Economics and Management. Vol. 15 (2): $197-217$. 